\title{
Analisis Kinerja Pegawai Melalui Pelaksanaan Pendidikan Dan Pelatihan Kepemimpinan Pada Badan Perencananaan Pembangunan Daerah Provinsi Riau Tahun 2019
}

\author{
Desi Devrika Devra \\ Universitas Islam Negeri Sultan Syarif Kasim, Indonesia \\ e-mail: desi.devrikadevra@gmail.com
}

\begin{abstract}
Abstrak
Tujuan penelitian ini untuk menganalisis bagaimana kinerja Aparatur Sipil Negara pada Badan Perencanaan Pembangunan Daerah Provinsi Riau melalui pelaksanaan pendidikan dan pelatihan daerah Provinsi Riau. Metode penelitian ini bersifat deskriftif kualitatif dengan teknik tipologi sebagai strategi penelitian dengan jumlah informan berjumlah 20 orang. Hasil penelitian menunjukkan bahwa tidak semua tahapan struktur kurikulum dalam pelaksanaan pendidikan dan pelatihan kepemimpinan tingkat IV yang di ikuti oleh pejabat struktural eselon IV yang ada di Badan Perencanaan Pembangunan Daerah dapat terlaksana dengan baik, dimana tahapan laboratorium kepemimpinan belum bisa terlaksana dikarenakan masih terbatasnya sarana dan prasarana yang dimiliki serta minimnya anggaran yang diperuntukkan bagi pengembangan sumber daya aparatur yang ada di Pemerintah Provinsi Riau. Aparatur Sipil Negara khususnya pejabat struktural eselon IV yang ada di Badan Perencanaan Pembangunan Daerah Provinsi Riau sudah mampu bekerja secara profesional dan memiliki kinerja yang baik setelah mengikuti pendidikan dan pelatihan kepepimpinan tingkat IV karena mereka telah mengalami peningkatan pengetahuan dalam bekerja, memiliki jiwa sebagai pembaharu dalam organisasi, menumbuhkan sikap untuk senantiasa memberikan pelayanan yang terbaik.
\end{abstract}

Keywords: Kinerja, Pendidikan dan Pelatihan Kepemimpinan Tingkat IV, Bappeda Provinsi Riau

\begin{abstract}
The purpose of this research is to analyze how civil apparatus performance in the Regional Development Planning Board of Riau Province through the implementation of education and training of Riau province. This research method is a qualitative deskriftif with typology techniques as a research strategy with the number of informant amounting to 20 people. The results showed that not all phases of curriculum structure in the implementation of education and leadership training level IV followed by the structural office of Echelon IV in the Regional Development Planning Board can be carried out well, where the stage of leadership laboratory can not be carried out due to still limited facilities and infrastructure owned and lack of budget for the development of apparatus resources in Riau province government. State civil apparatus, especially echelon structural officials who exist in the Regional Development Planning Board of Riau Province has been able to work professionally and have good performance after following the education and training of level IV leadership because they have experienced an increase in the knowledge in working, have a soul as a reformer in the organization, foster a attitude to always provide the best service.
\end{abstract}

Kata Kunci : Performance, Education and Training of Leadership Level IV, Bappeda of Riau Province 


\section{PENDAHULUAN}

Kinerja aparatur pemerintah daerah, memang terlihat jauh lebih baik jika dibandingkan dengan keadaan pada dua atau tiga dekade yang lampau. Namun dikalangan pemerintah, utamanya pemerintah daerah, masih terlihat birokrat-birokratnya yang masih bersifat formaistik, bahkan ritualistik. Prosedur pelayanan publik yang berbelit-belit dan kadang-kadang menjengkelkan publik masih belum lenyap atau berkurang. Ketidakpuasan masyarakat terhadap pelayanan aparatur pemerintah seperti yang dilansir oleh Tjokroamidjojo (2005) dan beberapa media massa lainnya mengidentifikasikan kekurang mampuan dan kelemahan aparatur dalam melaksanakan tugasnya. Dengan kata lain, konidisi yang demikian ini disebabkan oleh administratif incapacity (Bryant and White, 2002). Kesemuanya itu pada hakekatnya menunjukkan gejala rendahnya tingkat kemampuan administratif para aparat.

Berlakunya Undang-undang Nomor 23 Tahun 2014 tentang otonomi daerah telah memberikan perubahan dalam penyelenggaraan pemerintahan. Setiap daerah diberi kewenangan dan dituntut untuk meningkatkan kemandirian daerah baik dalam hal keuangan maupun kualitas sumber daya manusianya. Dengan adanya pemberlakuan undang-undang dimaksud maka pemerintah daerah berupaya untuk lebih meningkatkan kualitas sumber daya aparatur disegala bidang karena peran sumber daya manusia pada masa kini akan menjadi penentu bagi keberhasilan pembangunan. Peningkatan sumber daya manusia diharapkan dapat meningkatkan kinerja organisasi dalam memberikan pelayanan prima kepada masyarakat.

Pelatihan adalah suatu proses mengajarkan keterampilan yang dibutuhkan pegawai untuk melakukan tugas atau pekerjaan tertentu. Dengan diberikannya pendidikan dan pelatihan diharapkan pegawai mampu bekerja lebih efisien dan pegawai mampu melaksanakan tugas dengan lebih baik, sehingga dapat terwujud terciptanya tenaga aparatur perencanaan pembangunan yang handal, sesuai dengan tujuan dan sasaran yang telah ditetapkan.

Salah satu Diklat yang tujuan utamanya agar setiap pegawai mampu bekerja lebih efisien dan pegawai mampu melaksanakan tugas dengan lebih baik adalah Pendidikan dan Latihan Kepemimpinan (Diklat Pim) II, III dan IV. Syarat untuk peserta Pendidikan dan Latihan Kepemimpinan II untuk ASN yang telah menduduki Eselon IIIa (Sarjana), Pendidikan dan Pelatihan III untuk ASN yang telah menduduki Eselon IVa dan perangkat paling rendah IIIc (Sarjana) dan Pendidikan dan Pelatihan IV untuk ASN dengan pangkat paling rendah IIIb (Sarjana). Pendidikan dan latihan kepemimpinan atau sering disingkat dengan Diklat Pim merupakan salah satu jenis Pendidikan dan Pelatihan yang diperlukan dalam pembentukan kinerja ASN untuk jabatan struktural Eselon II, III dan IV. Dengan diadakannya Diklat Pim ini diharapkan aparatur pemerintahan memiliki peningkatan kemampuan serta keterampilan dalam menjalankan tugas-tugas. (Admosudirjo, 2006)

Terkait permasalahan yang ditemui penulis dari hasil pelaksanaan Pendidikan dan Latihan (Diklat) Kepemimpinan IV yang telah diikuti oleh para pejabat sturktural eselon IV pada Badan Perencanaan Pembangunan Daerah Provinsi Riau di ini adalah sebagai berikut:

1) Masih ditemuinya pejabat struktural eselon IV yang belum mengetahui secara jelas kedudukan, tugas dan fungsi jabatan pada organisasi Badan Perencanaan Pembangunan Daerah Provinsi Riau sehingga pegawai tersebut sering mengalami kesulitan dalam menjalankan visi dan misi organisasi.

2) Adanya ketidakkmampuan pejabat struktural eselon IV yang telah menggikuti Diklat Pim IV dalam melakukan koordinasi dan hubungan kerja dengan baik dan benar baik dengan bawahan maupun dengan atasan sehingga prosedur dan mekanisme kerja yang tertuang dalam Rencana kerja (Renja) dan Rencana Strategi (Renstra) pada Bappeda Provinsi Riau tidak dapat berjalan sebagaimana mestinya. 
3) Rendahnya kemampuan pejabat struktural eselon IV dalam pengambilan keputusan yang tepat sesuai dengan kewenangan dan prosedur yang berlaku di unit kerjanya serta rendahnya kemampuan mereka dalam menerapkan teknik pengelolaan, penyampian informasi dan pelaporan yang efektif dan efisien.

\section{METODE}

Penelitian ini menggunakan pendekatan kualitatif dengan studi kasus sebagai strategi penelitian. Pendekatan ini diarahkan pada latar dan individu secara utuh. Metode penelitian bukan hanya merupakan sekumpulan metode atau teknik penelitian semata, melainkan juga merupakan landasan nilai-nilai, asumsi-asumsi, etika dan norma yang menjadi aturan standard yang dipergunakan untuk menafsirkan serta menyimpulkan data penelitian. Jenis penelitian yang dipakai didalam penelitian ini memakai pendekatan kualitatif, karena hanya menggambarkan apa adanya dari suatu variabel, gejala atau keadaan dan tidak bermaksud untuk menguji hipotesis. (Arikunto, 2005).

Beberapa pertimbangan mengapa digunakan metode pendekatan kualitatif, yakni: pertama, bila peneliti berhadapan dengan kenyataan ganda mudah disesuaikan; kedua, menyajikan secara langsung hakikat hubungan antara peneliti dan responden; ketiga, lebih peka dan lebih dapat menyesuaikan diri dengan banyak penajaman pengaruh bersama dan pola-pola nilai yang dihadapi (Riduwan, 2006). Hasil data yang diperoleh dilakukan dengan menggunakan metode deskriptif analitis.

\section{HASIL DAN PEMBAHASAN}

\section{Pelaksanaan Pendidikan dan Latihan Kepemimpinan (Diklat Pim) IV di Badan Perencanaan Pembangunan Daerah (Bappeda) Provinsi Riau.}

Badan Perencanaan Pembangunan Daerah (Bappeda) Provinsi Riau sebagai instansi pemerintah yang memiliki tugas pokok membantu Kepala Daerah dalam menyelenggarakan sebagian tugas umum pemerintahan dan pembangunan di bidang perencanaan pembangunan serta penilaian atas pelaksanaannya, dituntut untuk memiliki sumber daya manusia yang memiliki kompetensi jabatan dalam penyelenggaraan Negara dan pembangunan. Untuk mendapatkan sumber daya manusia yang memiliki kompetensi tersebut para pegawai dituntut untuk meningkatkan pengetahuan, keahlian, dan keterampilan yang berkenaan dengan tugas dan pekerjaan mereka. Oleh karena itu, perlu dilakukan pengembangan keahlian dan keterampilan pegawai yang salah satu caranya melalui pelaksanaan pendidikan dan pelatihan (Diklat).

Tujuan utama dari Diklat adalah meningkatkan pengetahuan, keahlian, keterampilan, dan sikap untuk dapat melaksanakan tugas jabatan secara profesional sesuai kebutuhan instansi. Selain itu, tujuan Diklat adalah untuk menciptakan kesamaan visi dan dinamika pola pikir dalam melaksanakan tugas pemerintahan umum dan pembangunan demi terwujudnya kepemerintahan yang baik. Sedangkan sasaran dari Diklat adalah terwujudnya pegawai yang memiliki kompetensi yang sesuai dengan persyaratan jabatan masing-masing.

Sementara itu sasaran utama dalam penyelengaran Pendidikan dan Pelatihan Kepemimpinan IV adalah untuk mengembangkan kompetensi kepemimpinan pejabat struktural eselon IV yang akan berperan dalam melaksanakan tugas dan fungsi kepemerintahan di instansinya masing-masing. Dengan demikian, maka sasaran penyelengaran Diklat Kepemimpinan IV adalah dihasilkannya Pegawai Negeri Sipil yang memilki kemampuan memimpin pada jenjang jabatan struktural eselon IV. Kemampuan memimpin tersebut diwujudkan dengan kemampuanya dalam memimpin perubahan di unit kerjanya. Perubahan ini hanya dapat terwujud jika pejabat struktural tersebut mampu menetapkan area dan fokus 
perubahan, lalu kemudian mempengaruhi dan memobilsasi para stakeholder mendukung perubahan tersebut.

Sejalan dengan tujuan dan sasaran di atas, maka detail kompetensi yang dibangun pada Diklat Pim IV adalah kompetensi kepemimpinan operasional yaitu kemampuan membuat perencanan kegiatan instansi dan memimpin keberhasilan implementasi pelaksanan kegiatan tersebut, yang diindikasikan dengan kemampuan:

1) Membangun karakter dan sikap perilaku integritas sesuai dengan peraturan perundangan dan kemampuan untuk menjunjung tinggi etika publik, taat pada nilai-nilai, norma, moralitas dan bertangungjawab dalam memimpin unit instansinya.

2) Membuat perencanaan pelaksanan kegiatan instansi.

3) Melakukan kolaborasi secara internal dan eksternal dalam mengelola tugas-tugas organisasi kearah efektifitas dan efisiensi pelaksanan kegiatan instansi.

4) Melakukan inovasi sesuai bidang tugasnya guna mewujudkan pelaksanan kegiatan yang lebih efektif dan efisien.

5) Mengoptimalkan seluruh potensi sumber daya internal dan eksternal organisasi dalam implementasi strategi kebijakan unit instansinya.

Sesuai dengan tujuan penelitian ini yaitu menganalisis kinerja Aparatur Sipil Negara melalui pelaksanaan Pendidikan Dan Latihan Kepemimpinan (Diklat Pim) IV di Badan Perencanaan Pembangunan Daerah Provinsi Riau, maka penulis akan menguraikan dan menjelaskan hal-hal tersebut didukung oleh data dan informasi yang berhasil diperoleh baik dari fenomena dilapangan, hasil wawancara dan data yang peneliti peroleh dari informan penelitian sebagaimana teknik triangulasi sumber yang peneliti gunakan yaitu membandingkan data hasil pengamatan dengan data hasil wawancara dengan semua pihak yang terkait dalam penelitian ini serta membandingkan hasil wawancara dengan isi suatu dokumen yang berkaitan.

\section{A. Struktur Kurikulum}

Struktur Kurikulum merupakan pola dan susunan mata pelajaran yang harus ditempuh oleh peserta didik dalam kegiatan pembelajaran kedalam muatan kurikulum setiap mata pelajaran pada setiap tahun pendidikan yang dituangkan dalam kompetensi yang harus dikuasai peserta didik Diklat Pim IV dari Badan Perencanaan Pembangunan Daerah Provinsi Riau sesuai dengan beban belajar yang tercantum dalam struktur kurikulum.

Diklat Kepemimpinan Tingkat IV merupakan program yang akan mentransformasi peserta Diklat menuju tujuan yang telah ditetapkan dalam program Diklat Kepemimpinan Tingkat IV ini. Setiap peserta Diklat akan melalui serangkaian proses yang telah disusun untuk membawa peserta kepada tujuan yang telah ditetapkan. Oleh karena itu, setiap peserta perlu memahami tujuan dan rangkaian proses tersebut agar dapat mengikuti program Diklat Kepemimpinan Tingkat IV secara lebih terarah. Tujuan dan rangkaian proses mengandung unsur akademik dan administratif. Aspek akademik meliputi kompetensi yang akan dibangun, struktur kurikulum, dan strategi pembelajarannya. Sedangkan aspek administratif meliputi dasar hukum dan tata tertib.

Sebagaimana diketahui dalam pelaksanaan Pendidikan dan Latihan Kepemimpinan IV (Diklat Pim IV) bagi pejabat struktural eselon IV di Badan Perencanaan Pembangunan Daerah Provinsi Riau, Struktur kurikulum haruslah ditempuh oleh peserta didik dalam kegiatan pelayanan kedalam muatan kurikulum pada setiap mata pelajaran yang dituangkan kedalam kompetensi-kompetensi yang terdiri atas standar kompetensi, dan kompetensi dasar yang dikembangkan berdasarkan standar kompetensi lulusan yang harus dikuasai peserta didik sesuai dengan beban belajar yang tercantum dalam struktur kurikulum. Agar tercapainya tujuan dari Diklat Pim IV ini maka stuktur kurikulum yang akan disusun harus benarbenar tersusun dengan baik dan benar serta dapat dengan mudah dipahami oleh setiap peserta didik. 
Berdasarkan hasil observasi penulis dilapangan diketahui bahwa tahapan stuktur kurikulum terkait adanya pelaksanaan kegiatan laboratorium kepemimpinan sejauh ini belum dapat berjalan dengan baik dikarenakan sarana dan prasarana yang dimiliki saat ini belum mendukung untuk terbentuknya laboratorium kepemimpinan. Selain itu dibutuhkannya anggaran yang cukup besar untuk melaksanakan laboratorium kepemimpinan sehingga membuat hal tersebut sangat sulit untuk dipenuhi ditambah sampai saat ini Kantor BPSDM Provinsi Riau masih dalam tahap renovasi sehingga fokus untuk melaksanakan laboratorium kepemimpinan ini akan diusahakan untuk tahun anggaran selanjutnya.

\section{B. Persyaratan Peserta, Pencalonan dan Seleksi}

Pentingnya Diklat Pim IV diikuti oleh setiap pejabat struktural eselon IV di Bappeda Provinsi Riau adalah untuk dapat menciptakan pemimpin perubahan yang mampu melakukan perubahan terutama pada satuan Organisasi Perangkat Daerah (OPD) masing-masing tempat mereka bekerja dan mampu menghasilkan kinerja individu yang baik sehingga berimbas kepada kinerja organisasi Bappeda Provinsi Riau.

Dalam proses pelaksanaan Diklat Pim IV maka salah satu hal yang paling penting adalah adanya peserta yang mengikuti pelatihan tersebut, dimana persyaratan utama yang dapat mengikuti adalah ASN yang telah atau akan menduduki jabatan struktural eselon IV. Adapun persyaratan peserta, pencalonan dan seleksi peserta yang berhak mengikuti pelaksanaan Diklat Pim IV ini dilingkungan Pemerintah Provinsi Riau adalah sebagai berikut:

A. Persyaratan Pribadi

B. Kelengkapan dan persyaratan yang harus dibawa

Dari persyaratan diatas dapat terlihat bahwa persyaratan dalam pelaksanaan Diklat Pim IV di Pemerintah Provinsi Riau telah diterapkan dengan sebaik-baiknya dimana persyaratan pribadi dan persyaratan administrasi dibuat serinci mungkin agar setiap peserta dapat lebih berkonsentrasi didalam mengikuti setiap sesi Diklat Pim IV yang diikuti.

Selanjutnya setelah ditentukan persyaratan pribadi dan persyaratan administrasi maka dilakukan proses pencalonan dan seleksi siapa-siapa saja ASN yang boleh mengikuti Diklat Pim IV tersebut hal ini ditentukan berdasarkan kepada usulan dari pimpinan masing-masing satuan kerja dalam hal ini Kepala Bappeda Provinsi Riau yang ingin mengajukan bawahannya untuk mengikuti pencalonan dan seleksi peserta Diklat Pim IV.

Berdasarkan hasil observasi penulis dilapangan diketahui bahwa selama ini Bappeda Provinsi Riau telah maksimal didalam melakukan pencalonan dan seleksi peserta Diklat Pim IV yang berasal dari Bappeda Provinsi Riau, namun dalam proses perjalanannya masih ditemui beberapa pejabat stuktural yang baru menduduki jabatan struktural eselon IV belum sama sekali mengikuti Diklat Pim IV hal ini dikarenakan yang bersangkutan masih memiliki tanggung jawab pekerjaan yang membutuhkan ASN tersebut untuk terus bekerja sehingga berhalangan untuk mengikuti Diklat Pim IV.

\section{Tenaga kediklatan dan Kompetensi Widyaiswara}

Tenaga Kediklatan merupakan Tenaga Pengajar/Widyaiswara sebagaimana yang telah mengikuti diklat bagi pengajar (Training of Trainer) atau pendidikan lain yang sejenis serta memiliki kompetensi untuk mampu memberikan materi pembelajaran dan menguasai metodologi pembelajaran. Dalam Peraturan Pemerintah No. 101 Tahun 2001 menyebutkan batasan Pendidikan dan Pelatihan Jabatan Pegawai Negeri Sipil (Diklat) adalah proses penyelenggaraan belajar mengajar dalam rangka meningkatkan kemampuan Pegawai Negeri Sipil.

Berdasarkan hasil observasi penulis dilapangan diketahui bahwa yang berhak mengajar pada pelaksanaan Diklat Pim IV yang diselenggarakan oleh BPSDM Provinsi Riau adalah orang-orang yang 
memenuhi ketentuan pedoman diklat yaitu Widyaiswara, Tenaga kediklatan lainnya, Pengelola Lembaga Diklat dan sejauh ini hal tersebut dapat terpenuhi.

\section{Metode Diklat dan Sarana dan Prasarana}

Metode adalah seperangkat langkah (apa yang harus dikerjakan) yang tersusun secara sistematis (urutannya logis). Sedangkan Metode Diklat adalah suatu langkah-langkah yang tersusun secara sistematis dalam proses pelaksanaan pendidikan dan pelatihan yang dilaksanakan.

Setiap pendidikan dan pelatihan memiliki tujuan yang berbeda-beda menurut Wursanto (1996) bahwa pendidikan dan latihan memiliki tujuan sebagai berikut:

1) Menambah pengetahuan pegawai

2) Menambah keterampilan pegawai

3) Mengubah dan membentuk sikap pegawai

4) Mengembangkan keahlian pegawai, sehingga pekerjaan dapat diselesaikan dengan cepat dan efektif

5) Mengembangkan semangat, kemauan dan kesenangan kerja pegawai

6) Mempermudah pengawasan terhadap pegawai

7) Mempertinggi stabilitas pegawai.

Berdasarkan hasil observasi penulis dilapangan diketahui dalam menyusun sebuah metode diklat BPSDM Provinsi Riau telah memiliki metode yang tersusun dengan baik dan terencana.

\section{E. Waktu Pelaksanaan}

Sebagai satuan kerja yang bertugas menyelenggarakan Diklat Pim IV di Lingkungan Pemerintah Provinsi Riau, BPSDM Provinsi Riau dalam menetapkan waktu pelaksanaan Diklat Pim IV yang diikuti oleh pejabat eselon IV di Bappeda Provinsi Riau yaitu sesuai dengan program dan kegiatan yang disusun sekali dalam satu tahun sesuai dengan mata anggaran pada Anggaran Pendapatan dan Belanja Daerah (APBD) Provinsi Riau.

Berdasarkan hasil observasi penulis dilapangan diketahui bahwa untuk waktu pelaksanaan Diklat Pim IV yang diikuti oleh pejabat struktural eselon IV di Bappeda Provinsi Riau materi diklat telah tersusun dengan baik dimana setiap tahunnya Diklat Pim IV dapat terlaksana. Selain itu dalam sesi pelaksanaannya juga telah ditata dengan sebaik mungkin namun ada kelemahan didalam sesi pelaksanaan Diklat Pim IV tersebut dimana dalam sesi praktek belum bisa maksimal dilaksanakan dikarenakan masih terbatasnya sarana dan prasarana yang dimiliki oleh BPSDM Provinsi Riau.

\section{F. Pembiayaan}

Pembiayaan adalah semua pengorbanan yang perlu dilakukan untuk suatu proses kegiatan yang dilaksanakan, yang dinyatakan dengan satuan uang menurut harga kebutuhan yang berlaku, baik yang sudah terjadi maupun yang akan terjadi. Biaya terbagi menjadi dua, yaitu biaya eksplisit dan biaya implisit. Biaya eksplisit adalah biaya yang terlihat secara fisik, misalnya berupa uang. Sementara itu, yang dimaksud dengan biaya implisit adalah biaya yang tidak terlihat secara langsung, misalnya biaya kesempatan dan penyusutan barang modal.

Terkait dengan pembiayaan dalam pelaksanaan Diklat Pim IV yang diikuti oleh pejabat struktural eselon IV di Bappeda Provinsi Riau pada BPSDM Provinsi hal ini dilakukan dengan cara mengajukan kebutuhan dana melalui APBD Provinsi Riau, kebutuhan dana yang diinginkan digambarkan didalam Rencana Kerja Anggaran (RKA) dengan merincikan segala kebutuhan-kebutuhan yang diperlukan selama pelaksanaan Diklat Pim IV berlangsung.

Berdasarkan hasil obervasi penulis dilapangan diketahui bahwa dalam proses pembiayaan untuk pelaksanaan Diklat Pim IV yang diikuti oleh pejabat struktural eselon IV di Bappeda Provinsi Riau pada BPSDM Provinsi Riau sejauh telah dianggarkan didalam APBD Provinsi Riau pada setiap tahunnya dan setiap peserta tidak dipungut bayaran. 


\section{G. Evaluasi}

Evaluasi adalah suatu proses untuk menyediakan informasi tentang sejauh mana suatu kegiatan tertentu telah dicapai, bagaimana perbedaan pencapaian itu dengan suatu standar tertentu untuk mengetahui apakah ada selisih di antara keduanya, serta bagaimana manfaat yang telah dikerjakan itu bila dibandingkan dengan harapan-harapan yang ingin diperoleh

Terkait pelaksanaan evaluasi terhadap penyelenggaraan Dikat Pim IV yang diikuti oleh pejabat struktural eselon IV di Bappeda Provinsi Riau hal ini dapat diketahui bahwa evaluasi dalam pelaksanaan Diklat Pim IV dilakukan kepada setiap peserta yang mengikutinya juga terhadap sistem pelaksanaan didalam penyelenggaraanya, hal ini sangat penting mengingat evaluasi ini bertujuan untuk mengetahui sejauhmana hasil-hasil yang telah dicapai oleh setiap peserta dan panitia pelaksana didalam proses pelaksanaan Diklat Pim IV yang diikuti.

Berdasarkan hasil observasi penulis dilapangan diketahui bahwa evaluasi pelaksanaan Diklat Pim IV yang diikuti oleh pejabat struktural eselon IV di Bappeda Provinsi Riau telah berjalan dengan baik dimana terstrukturnya item-item yang menjadi dasar penilaian dan pengevaluasian setiap peserta Diklat dari pejabat struktural eselon IV di Bappeda Provinsi Riau, selain itu dalam proses penyelenggaraanya juga terlihat koordinasi dan komunikasi yang baik dan harmonis antara pejabat stuktural dilingkungan BPSDM Provinsi Riau, sehingga hal ini menjadi sesuatu yang baik didalam proses mewujudkan pejabat struktural eselon IV di Bappeda Provinsi Riau yang memiliki integritas dan kinerja yang baik.

\section{Kinerja Aparatur Sipil Negara Badan Perencanaan Pembangunan Daerah Provinsi Riau Setelah Mengikuti Pelaksanaan Diklat Pim IV}

Pegawai yang terampil dan handal sangat dibutuhkan dalam mengaplikasikan seluruh kegiatan manajemen pada saat ini. Kinerja pegawai perlu diperhatikan serta ditingkatkan dengan baik untuk mendukung tujuan visi dan misi yang telah ditetapkan dalam sebuah organisasi. Kinerja merupakan hasil pekerjaan yang mampu dicapai secara kualitas dan kuantitas dengan penuh tanggung jawab yang telah ditetapkan dan disepakati bersama di dalam suatu organisasi. Kinerja juga harus mampu memperhatikan periode waktu untuk melaksanakan dan mencapai target yang diinginkan dalam suatu organisasi. Dalam sebuah organisasi kinerja pegawai memegang peranan penting sebab dalam rangka pencapaian tujuan dari suatu organisasi dibutuhkan dukungan pegawai yang kompeten di bidangnya.

Pengembangan kapasitas aparatur merupakan hak bagi Aparatur Sipil Negara (ASN) untuk mendapatkan keahlian yang berguna dalam mendukung suatu organisasi sebagaimana yang tertuang dalam pasal 22 Undang Undang Nomor. 5 Tahun 2014 tentang Aparatur Sipil Negara. Kebijakan pengembangan sumberdaya aparatur selain bertujuan meningkatkan wawasan aparatur sebagai abdi negara dan abdi masyarakat dalam ukuran yang seimbang, juga meningkatkan profesionalisme agar aparatur sipil negara lebih aktif dan efisien. Untuk itu pengembangan sumber daya aparatur perlu dilakukan, karena dengan kegiatan tersebut akan terjadi peningkatan kemampuan pegawai, baik kemampuan profesionalnya, kemampuan wawasannya, kemampuan kepemimpinannya maupun kemampuan pengabdiannya. Salah satu instrument penting dalam pengembangan sumber daya aparatur melalui pendidikan dan pelatihan.

Dalam Keputusan Kepala LAN Nomor 13/2013 untuk mengukur kinerja dalam pelaksanaan Diklat Pim IV dapat dilakukan melalui:

1) Adanya Peningkatan pengetahuan.

2) Menciptakan aparatur yang mampu berperan sebagai pembaharu.

3) Memantapkan ASN beroritasi pemberdayaan sikap.

4) Adanya Semangat pengabdian .

5) Adanya Kesamaan visi dan pola pikir. 
Untuk mengetahui bagaimana Kinerja Aparatur Sipil Negara Badan Perencanaan Pembangunan Daerah Provinsi Riau setelah mengikuti Diklat Pim IV yang dilaksanakan oleh BPSDM Provinsi Riau dapat diketahui dari uraian berikut ini:

\section{1) Peningkatan Pengetahuan Melalui Pelaksanaan Pendidikan Dan Latihan Kepemimpinan IV}

Terkait bagaimana pentingnya pelaksanaan Diklat Pim IV dalam meningkatkan kemampuan teknis, teoritis, konseptual, moral pegawai sesuai dengan kebutuhan jabatan dari pejabat struktural eselon IV di Bappeda Provinsi Riau hal ini dapat diketahui bahwa dalam pelatihan Diklat Pim IV dimaksudkan untuk menghilangkan kekurangan baik yang ada sekarang maupun yang akan datang yang meyebabkan pegawai bekerja dibawah standar yang diinginkan. Pendidikan dan pelatihan tingkat IV yang diikuti oleh pejabat struktural eselon IV di Bappeda Provinsi Riau mempunyai fokus peningkatan kompetensi pegawai berupa keahlian yang bakal memberikan manfaat bagi organisasi secara cepat. Manfaat-manfaat pendidikan dan pelatihan bagi organisasi pada umumnya dapat dirasakan dengan segera setelah pegawai tersebut saat mereka kembali bertugas.

Berdasarkan hasil obervasi penulis dilapangan diketahui bahwa Diklatpim IV ini memberikan dampak yang cukup baik terhadap pengetahuan kepemimpinan pejabat struktural eselon IV di Bappeda Provinsi Riau. Namun tetap saja ada sebagian kecil pejabat struktural eselon IV di Bappeda Provinsi Riau yang ternyata tidak memperoleh manfaat apapun dari keikutsertaannya dalam Diklatpim IV. Hal ini tentu saja sangat merugikan bagi pejabat yang bersangkutan dan instasi tempatnya bekerja.

\section{2) Menciptakan Aparatur Yang Mampu Berperan Sebagai Pembaharu}

Terkait bagaimana pentingnya peran Diklat Pim IV yang diikuti oleh pejabat struktural eselon IV yang ada di Bappeda Provinsi Riau dalam rangka menumbuhkan jiwa pembaharu dalam organisasinya, hal ini dapat diketahui bahwa untuk menjamin penyelenggaraan pemerintahan yang baik (Good Govermence), mutlak di perlukan adanya aparatur pemerintah yang berkualitas, teruji professional dan memiliki jiwa pembaharu. Perbaikan kualitas sumber daya manusia bagi pegawai dapat dilakukan melalui pendidikan dan pelatihan seperti Diklat Pim IV. Sistem pendidikan yang baik dan benar, sudah barang tentu akan menghasilkan pegawai-pegawai yang berkualitas tinggi dan sesuai dengan kompetensi yang di butuhkan.

Berdasarkan hasil obervasi penulis dengan salah seorang pejabat struktural eselon IV di Bappeda Provinsi Riau yang pernah mengikuti Diklat Pim IV yang dilaksanakan oleh BPSDM Provinsi Riau terkait dengan kemampuannya dalam memimpin, diketahui dari hasil wawancara berikut ini:

"Sebelum saya mengikuti Diklatpim IV saya kurang mampu dalam bertindak sebagai seorang pemimpin, saya selalu ragu dan tidak tahu harus bagaimana dalam memimpin sebuah tim kerja. Namun setelah saya mengikuti Diklatpim IV ini saya jadi tahu bagaimana seorang pemimpin dalam bertindak, dalam mengatasi permasalahan dan dalam menghadapi perbedaan pendapat dan secara pribai saya merasa memiliki jiwa sebagai pembaharu dalam tim kerja yang saya pimpin saat ini”.

Selanjutnya penulis melakukan wawancara dengan salah seorang staf pada Sub Bidang Statistik Bappeda Provinsi Riau terkait adanya peningkatan kemampuan pimpinannya dalam memimpin setelah mengikuti Diklat Pim IV, sebagaimana hasil wawancara berikut ini:

"Saya melihat sudah ada perubahan sebelum dan sesudah pimpinan saya mengikuti Diklat Pim IV, dan saya sangat merasakan perbedaan tersebut, dimana pimpinan lebih mendengarkan masukan dari bawahan, dan mampu menjalin komunikasi dengan kami sebagai bawahan". 
Sejalan dengan tuntutan publik akan kinerja Aparatur Pemerintah yang lebih profesional menjadi tantangan tersendiri bagi setiap Aparatur Sipil Negeri (ASN) untuk meningkatkan kualitas dan kapasitasnya. Untuk itu dengan bekal pengetahuan, pengalaman, ilmu dan teknologi yang dimiliki, seorang ASN diharapkan dapat menggenjot dirinya untuk memberikan dan membawa pembaharuan bagi kemajuan organisasi, sehingga dapat memberikan manfaat yang dapat diperhitungkan oleh instansi masing-masing.

\section{3). Memantapkan ASN Berorientasi Pemberdayaan Sikap}

Terkait pentingnya pelaksanaan Diklat Pim IV dalam membentuk sikap dari ASN dari pejabat struktural eselon IV yang ada di Bappeda Provinsi Riau, hal ini dapat diketahui bahwa dari segi sikap, diklat mengajarkan pegawai tentang tanggungjawab terhadap tugas yang diemban dan mampu memberikan contoh dan teladan bagi pegawai yang ada di level bawah selain itu aktualisasi terhadap tujuan pekerjaan lebih terarah dan mampu dikoordinir dengan baik.

Aparatur Sipil Negara (ASN) sebagai unsur utama SDM Aparatur Negara mempunyai peranan menentukan keberhasilan penyelenggaraan pemerintah dan pembangunan. Sosok ASN yang mampu memainkan peran tersebut adalah ASN yang mempunyai kompetensi yang diindikasikan dari sikap dan perilakunya yang penuh dengan kesetiaan dan ketaatan kepada Negara, bermoral dan bermental baik, profesional, sadar akan tanggungjawabnya sebagai pelayan publik, serta mampu menjadi perekat persatuan dan kesatuan bangsa.

\section{4). Pelayanan, Pengayoman Dan Pemberdayaan Masyarakat}

Hasil wawancara dengan Sekretaris Bappeda Provinsi Riau terkait mengenai kemampuan pejabat struktural eselon IV Bappeda Provinsi Riau dalam memberikan pelayanan kepada masyarakat setelah mengikuti Diklat Pim IV yang dilaksanakan oleh BPSDM Provinsi Riau dapat diketahui dari hasil wawancara berikut ini:

"Menurut saya pelayanan yang diberikan oleh pegawai khususnya pejabat struktural eselon IV di Bappeda Provinsi Riau yang telah mengikuti Diklat Pim IV yang dilaksanakan oleh BPSDM Provinsi Riau selama ini cukup memuaskan. Apalagi mereka memang selalu dibina dan diberikan pelatihan agar memberikan pelayanan yang terbaik bagi masyarakat. Mengenai adanya keluhan dari masyarakat tentang rendahnya pelayanan yang diberikan oleh pegawai Bappeda Provinsi Riau, saya rasa itu hanya sebagian kecil saja atau oknum jadi tidak bisa disamaratakan kepada seluruh pegawai”.

Sementara itu bagaimana tanggapan salah seorang pejabat struktural eselon IV di Bappeda Provinsi Riau yang pernah mengikuti Diklat Pim IV yang dilaksanakan oleh BPSDM Provinsi Riau yang berkaitan dengan pelayanan yang telah diberikan kepada masyarakat seperti tergambar pada wawancara berikut ini:

"Menurut saya pelayanan yang telah kami berikan di Bappeda Provinsi Riau ini sudah sangat baik, baik itu oleh saya pribadi ataupun dari staf saya. Kalaupun ada yang memberikan pelayanan yang kurang baik, itu kan oknum dan biasanya adalah pegawai yang berada diluar pantau saya ataupun dilakukan diluar jam kerja, bisa saja jadi hal ini terjadi dikarenakan sikap dan moral pegawai tersebut yang tidak baik".

Berdasarkan hasil wawancara di atas dapat diketahui bahwa pelayanan yang telah diberikan pegawai Bappeda Provinsi Riau kepada masyarakat sudah cukup baik. Aparatur sipil negara selain sebagai abdi negara dan abdi masyarakat juga merupakan pengayom bagi masyarakat, dengan demikian setiap permasalahan yang ada di masyarakat hendaknya dapat diselesaikan dan dicarikan jalan keluarnya. 
Kesediaan dalam mengayomi masyarakat merupakan wujud kinerja kepemimpinan yang bagi seorang pegawai. Untuk itu kesediaan dalam mengayomi masyarakat ini hendaknya muncul sebagai suatu kesadaran pribadi dan bukan karena faktor keterpaksaan.

\section{5). Adanya Kesamaan Visi Dan Pola Pikir}

Pada dasarnya manusia memiliki 2 (dua) pola pikir, yaitu pola pikir positif (berkembang) dan pola pikir negatif (tetap). Dalam konteks selaku aparatur sipil negara, maka pola pikir aparatur sipil negara terbagi dua bagian yaitu pola pikir positif (pola pikir berkembang) dan pola pikir negatif (pola pikir tetap). Terkait bagaimana diperlukannya kesamaan visi dan misi dalam membentuk pola pikir dari seluruh pejabat struktural eselon IV di Bappeda Provinsi Riau yang pernah mengikuti Diklat Pim IV hal ini dapat diketahui dari hasil wawancara penulis dengan Sekretaris Bappeda Provinsi Riau sebagai berikut:

"Dalam mewukudkan visi dan misi organisasi, sangat dibutuhkan kesamaan persepsi dalam setiap pengambilan keputusan terkait penyelenggaraan roda organisasi. Kesamaan visi dan misi ini diharapkan dapat mempermudah mencapai program-program organisasi yang sudah direncanakan. Sejauh ini dalam pandangan saya kesamaan visi dan misi pejabat struktural eselon IV di Bappeda Provinsi Riau yang pernah mengikuti Diklat Pim IV telah berjalan sesuai harapan dan saya berharap kedepannya hal positif ini dapat terus dipertahankan".

Hal senada juga disampaikan oleh salah seorang pejabat struktural eselon IV di Bappeda Provinsi Riau yang pernah mengikuti Diklat Pim IV dan saat ini menjabat sebagai Kepala Sub Bidang Kerja Pembangunan Bappeda Provinsi Riau sebagai berikut:

"Selama saya mengikuti Diklat Pim IV di lingkungan Pemerintah Provinsi Riau saya benar-benar merasakan ada perubahan pola pikir saya tentang bagaimana cara berorganisasi dengn baik, hal yang paling ditekankan didalam pelaksanaan kegiatan tersebut adalah bagaimana setiap pegawai memiliki kesamaan visi dan misi untuk mencapai tujuan organisasi, dan saya sampai saat ini masih merasakan dampak dari pelaksanaan Diklat Pim IV tersebut".

Dari hasil wawancara diatas dapat diketahui bahwa pola pikir melalui pelaksanaan Pendidikan Dan Latihan Kepemimpinan IV (Diklat Pim IV) sudah terbentuk pada Bappeda Provinsi Riau harapan dengan adanya kesamaan pola pikir ini supaya tercapainya pelayanan yang excellent atau prima yang dilaksanakan oleh Bappeda Provinsi Riau.

\section{KESIMPULAN}

Berdasarkan hasil analisis data yang telah dilakukan tentang kinerja Aparatur Sipil Negara melalui pelaksanaan Pendidikan Dan Latihan Kepemimpinan (Diklat Pim) IV di Badan Perencanaan Pembangunan Daerah Provinsi Riau, dapat disimpulkan bahwa:

1) Tidak semua tahapan stuktur kurikulum dalam pelaksanaan Diklat Pim IV yang diikuti oleh Pejabat Struktural Eselon IV di Bappeda Provinsi Riau dapat terlaksana dengan baik dimana tahapan keempat yaitu Tahapan Laboratorium Kepemimpinan belum bisa terlaksana dikarenakan masih terbatasnya sarana dan prasarana yang dimiliki serta masih minimnya anggaran untuk BPSDM Provinsi Riau sehinggaa hal inilah yang menjadi kendala utama terkait tidak dapat terlaksananya dengan baik pelaksanaan Diklat Pim IV yang dilaksanakan oleh Pemerintah Provinsi Riau. 
2) Aparatur Sipil Negara khususnya Pejabat Struktural Eselon IV yang ada di Bappeda Provinsi Riau selama ini sudah bekerja secara profesional dan memiliki kinerja yang baik setelah melaksanakan Diklat Pim IV yang dilaksanakan oleh Pemerintah Provinsi Riau karena mereka mengalami peningkatan pengetahuan dalam bekerja, memiliki jiwa sebagai pembaharu dalam organisasi, menumbuhkan semangat pengabdian kepada negara, menumbuhkan sikap untuk senantiasa memberikan pelayanan, pengayoman dan pemberdayaan masyarakat dalam bekerja dan adanya kesamaan visi dan pola pikir antar sesama pegawai yang ada di Bappeda Provinsi Riau.

\section{SARAN}

Mengingat pentingnya kinerja Aparatur Sipil Negara melalui pelaksanaan Pendidikan Dan Latihan Kepemimpinan (Diklat Pim) IV di Badan Perencanaan Pembangunan Daerah Provinsi Riau, maka dengan ini disarankan :

1) Agar Pendidikan dan Pelatihan Kepemimpinan (Diklatpim) IV dapat meningkatkan kinerja pegawai pada Bappeda Provinsi Riau, sebaiknya instansi terkait menerapkan Diklatpim IV secara berkelanjutan dan penentuan peserta diklat dilakukan dengan memberikan kesempatan yang sama kepada seluruh pegawai sesuai dengan kebutuhan instansi.

2) Untuk meningkatkan kinerja pegawa Bappeda Provinsi Riau, hendaknya instansi d meningkatkan kemampuan pegawai dalam bekerja seperti meningkatkan kemampuan dalam menyelesaikan pekerjaaan sesuai target, meningkatkan kemampuan dalam membuat gagasan perbaikan dan perubahan, kemampuan membuat keputusan dan kemampuan menyesuaikan diri dengan lingkungan. Hal ini dapat dilakukan dengan cara menerapkan pola-pola tersebut pada pelaksanaan Diklatpim IV.

\section{DAFTAR PUSTAKA}

[1]. Arikunto, Suharsimi (2005). Prosedur Suatu Penelitian:Pendekatan Praktek, Edisi Revisi V. Jakarta: Penerbit Rineka Cipta.

[2]. Atmosudirdjo, Prajudi (2006). Dasar-Dasar Ilmu Administrasi. Jakarta:Ghalia Indonesia.

[3]. Bryant, C dan Louise G. White. (2002). Managing Development in the Third World. Boulder Colorado: Westview Press.

[4]. Keputusan Kepala Lembaga Administrasi Negara Nomor 13 Tahun 2013, Tentang Pedoman Penyelenggaraan Pendidikan dan Latihan Kepemimpinan. Jakarta: Lembaga Administrasi Negara.

[5]. Peraturan Pemerintah Nomor 53 Tahun 2010 tentang Disiplin Pegawai Negeri Sipil.

[6]. Peraturan Pemerintah Nomor 101 Tahun 2001 tentang Penyelenggarann Pendidikan Dan Pelatihan Bagi Pegawai Negeri Sipil

[7]. Riduwan (2006). Metode dan Teknik Menyusun Tesis, cetakan keempat, Bandung: Alfabeta. 
[8]. Tjokroamidjojo, Bintoro (2005). Perencanaan Pembangnan. Jakarta: Haji Masagung

[9]. Undang-undang Nomor 5 Tahun 2014 tentang Aparatur Sipil Negara. 